\title{
RNA Trafficking and Local Protein Synthesis in Dendrites: An Overview
}

\author{
Kelsey C. Martin ${ }^{1}$ and R. Suzanne Zukin ${ }^{2}$ \\ ${ }^{1}$ Department of Psychiatry and Biobehavioral Sciences, Department of Biological Chemistry, David Geffen School of Medicine, Semel Institute for \\ Neuroscience and Human Behavior, University of California, Los Angeles, California 90095-1761, and 2Department Neuroscience, Rose F. Kennedy Center, \\ Albert Einstein College of Medicine, Bronx, New York 10461
}

It is now widely accepted that mRNAs localize to dendrites and that translation of these mRNAs is regulated in response to neuronal activity. Recent studies have begun to reveal the underpinnings of these processes and to underscore the importance of local protein synthesis to synaptic remodeling and plasticity.

When Steward and Levy (1982) first reported their observation of polyribosomes at the base of spines, the prevailing view was that all proteins were synthesized in the cell body and then transported to distal compartments of neurons. Steward and Levy's discovery, however, raised the intriguing possibility that mRNAs could be transported to synapses and locally translated in response to synaptic stimulation. This provided an elegant mechanism for spatially restricting gene expression within the neuron, such that individual synapses could independently regulate their morphology and efficacy, in a persistent, protein synthesis-dependent manner, in response to specific stimuli. It is now widely accepted that mRNAs do localize to dendrites and that translation of these mRNAs contributes to synaptic plasticity. As is evident from the collection of Mini-Reviews on dendritic protein synthesis in this issue of The Journal of Neuroscience, the field has evolved to focus on a series of key questions, including the following: (1) what mRNAs are present in dendrites? (2) How are these mRNAs transported from the nucleus into the dendrite? (3) How is translation of these mRNAs regulated by neuronal activity? and (4) What is the function of local translation of specific transcripts? In this brief introductory overview, we will consider each of these questions in turn.

Key words: synaptic plasticity; mRNA trafficking; dendrites; transcriptional regulation; excitatory synapses; dendritic localization

\section{What mRNAs are present in dendrites?}

Using radioactive uridine precursors, Davis et al. (1987) demonstrated that RNAs were transported into dendrites of cultured hippocampal neurons. Subsequent in situ hybridization studies revealed the presence of specific mRNAs encoding cytosolic, cytoskeletal, and integral membrane proteins in dendritic layers of the hippocampus and at postsynaptic densities of hippocampal neurons in vivo and in vitro. These include mRNAs encoding microtubule-associated protein 2 (MAP2), (Garner et al., 1988; Kleiman et al., 1990), the $\alpha$-subunit of $\mathrm{Ca}^{2+} /$ calmodulindependent protein kinase II (CaMKII $\alpha$ ) (Miyashiro et al., 1994), brain-derived neurotrophic factor (BDNF), activity-regulated cytoskeleton-associated protein (Arc) (Lyford et al., 1995), tyrosine-related kinase $\mathrm{B}(\mathrm{TrkB})$ receptor, $\mathrm{IP}_{3}$ receptor, the atypical protein kinase $\mathrm{M} \zeta$, the NMDA receptor (NMDAR) NR1 sub-

Received April 27, 2006; revised May 26, 2006; accepted May 26, 2006.

This work was supported by grants from the W. M. Keck Foundation (K.C.M.), the McKnight Foundation (K.C.M.), the Burroughs Wellcome Fund (K.C.M.), and the FRAXA Foundation (R.S.Z.) and by National Institutes of Health Grant NS20752 (R.S.Z.).

Correspondence should be addressed to either of the following: Dr. R. Suzanne Zukin, Department of Neuroscience, Rose F. Kennedy Center, Room 602, Albert Einstein College of Medicine, 1300 Morris Park Avenue, Bronx, NY 10461, E-mail: zukin@aecom.yu.edu; or Dr. Kelsey C. Martin, Department of Psychiatry and Biobehavioral Sciences and Department of Biological Chemistry, Semel Institute for Neuroscience and Human Behavior, University of California, Los Angeles, CA 90095-1761, E-mail: kcmartin@mednet.ucla.edu.

D0I:10.1523/JNEUROSCI.1801-06.2006

Copyright $\odot 2006$ Society for Neuroscience $\quad$ 0270-6474/06/267131-04\$15.00/0 unit and glycine receptor $\alpha$ subunit (for review, see Steward and Schuman, 2003).

More recently, unbiased approaches to amplify mRNAs from purified dendritic and/or synaptic compartments (Miyashiro et al., 1994; Tian et al., 1999; Moccia et al., 2003; Sung et al., 2004) have generated lists of localized mRNAs numbering in the hundreds. These experiments suggest that there is a rich repertoire of mRNAs whose translation can be regulated in a spatially restricted manner in response to stimulation. Wide acceptance of the dendritic localization of such a large number of mRNAs, however, has been delayed by the lack of in situ hybridization data demonstrating that the mRNAs are indeed present in dendrites.

The population of dendritically localized mRNAs is likely to be regulated by development and by activity. Thus, many mRNAs localize to dendritic growth cones of developing neurons but are not present in dendrites of mature neurons (Crino and Eberwine, 1996). Other mRNAs appear to become dendritically localized in response to activity. One example is the mRNA encoding Arc, which is transcriptionally induced by activity and then rapidly transported into dendrites (Link et al., 1995; Lyford et al., 1995). Similarly, the dendritic localization of mRNAs encoding BDNF and trkB increases after neuronal activity (Tongiorgi et al., 1997, 2004). These findings suggest that the complement of mRNAs that is present in dendrites is dynamically regulated. 


\section{Export of mRNAs to neuronal processes}

Early, pioneering studies used nucleic acid stains and green fluorescent protein fused to RNA-binding proteins to visualize mRNA translocation in live neurons (Kohrmann et al., 1999; Kiebler and DesGroseillers, 2000; Huang et al., 2003; Tiruchinapalli et al., 2003). These studies showed that localized mRNAs are transported in the form of large granules containing mRNAs, RNA-binding proteins, ribosomes, and translational factors (RNA-containing granules) in a rapid (average speed, $0.1 \mu \mathrm{m} / \mathrm{s}$ ), bidirectional, and microtubule dependent manner (Knowles et al., 1996). As reviewed in the accompanying Mini-Review by Wells (2006), the dendritic localization of mRNAs appears to be mediated by a family of RNA-binding proteins. Disruption of RNA-binding proteins such as zipcode-binding protein (ZBP) 1 and 2, Staufen, or cytoplasmic polyadenylation element-binding protein (CPEB) impairs localization of targeted mRNAs (Zhang et al., 2001). These observations suggested a critical role for mRNA-binding proteins as molecular adapters between cisacting mRNA localization sequences and microtubule-based transport machinery. Of binding proteins known to mediate mRNA trafficking in dendrites, perhaps the best characterized is CPEB. CPEB facilitates mRNA targeting to dendrites (Huang et al., 2003) and triggers "on-site" translation in response to external signals (Shin et al., 2004).

Most of the cis-acting sequences that have been identified as being involved in dendritic localization are in the 3'UTR of the mRNA. Recent studies of oskar mRNA localization in Drosophila melanogaster oocytes have indicated that the nuclear history of the mRNA is important in mediating its ultimate localization and specifically that the complement of RNA-binding proteins that associate with mRNAs during processing in the nucleus have a significant impact on the localization of the mRNA in the cytoplasm (Hachet and Ephrussi, 2004). Proper identification of cisacting sequences that mediate dendritic localization will thus likely require analyses in systems in which reporter mRNAs undergo normal pre-mRNA processing in the nucleus.

Recent studies, described in the companion review by Hirokawa (2006), have begun to characterize the RNA granules that carry mRNAs into dendrites. In a tour de force, Hirokawa used affinity chromatography and proteomics to identify $>42$ proteins that constitute the large RNA-containing granule and showed that a subset of component proteins, such as hnRNP U (heterogeneous nuclear ribonucleoprotein), staufen, $\operatorname{PUR} \alpha$, and PSF (pyrimidine tract binding protein-associated splicing factor), are critical to dendritic RNA transport (Kanai et al., 2004). These investigators identified the kinesin superfamily protein KIF5 as a motor involved in the active transport RNA-containing granules into distal dendrites (Kanai et al., 2004). Whereas KIF5 is distributed to both axons and dendrites, RNA-containing granules are transported exclusively to dendrites (Kanai et al., 2004). In that neuronal mRNA transport is bidirectional, it is likely that future studies will uncover a role for dynein in retrograde mRNA transport.

As described above, the transport of mRNAs into dendrites appears to be regulated by neuronal activity. Synaptic stimulation in vivo delivers Arc mRNA to segments of dendrites with activated synapses and promotes on-site synthesis of Arc protein (Steward et al., 1998; Steward and Worley, 2001). Depolarization of hippocampal neurons in culture promotes movement of CaMKII $\alpha$ mRNA granules within dendrites (Rook et al., 2000) and the transport of a $\beta$-actin mRNA/ZBP1 complex into dendrites and spines (Tiruchinapalli et al., 2003). Dopamine receptor activation promotes transport of endogenous mRNAs such as glutamate receptor subunit 1 (GluR1) and GluR2 (Smith et al., 2005). These findings are, in principle, consistent with a model in which activated or "tagged" synapses might recruit mRNAs, thereby enabling activity-dependent regulation of local protein synthesis and synaptic efficacy.

\section{Translational regulation of mRNAs at the synapse}

The mRNAs that are present in RNA granules are thought to exist in a dormant state. Thus, an important aspect of mRNA localization involves the repression of mRNA translation until a specific stimulus activates translation. Studies of activity-dependent translation in dendrites have indicated a central role for rapamycin-dependent regulation at the level of translation initiation (Klann and Dever, 2004), described in more detail in the companion reviews by Pfeiffer and Huber (2006) and Wells (2006). In addition to this more classical means of translational regulation, Edelman and colleagues (Pinkstaff et al., 2001) have suggested that dendritic mRNAs are preferentially translated via internal ribosomal entry sites. Two recent studies have discovered a role for microRNA (miRNA)-mediated translational regulation in dendrites. In one study, Kunes and colleagues (Ashraf et al., 2006) found that the mRNA encoding CaMKII $\alpha$ was present in dendrites of Drosophila neurons, in which its translation was regulated during olfactory learning. They noted that the 3'UTR contained two putative miRNA-binding sites, indicating that binding of miRNAs might function to repress translation. Importantly, Kunes and colleagues (Ashraf et al., 2006) found that components of the miRNA processing machinery were also present at synapses and further found that one of these proteins, encoding the RNA helicase armitage, was degraded at the synapse during learning. Together, these findings suggest that persistent generation of miRNAs is required to repress translation and that neuronal activity leads to degradation of components of the RNA interference machinery such that miRNAs are no longer generated, thereby lifting translational repression. In another study, Greenberg and colleagues (Schratt et al., 2004, 2006) used bioinformatics approaches to look for potential miRNA binding sites in a group of mRNAs that they had previously shown to be translated in cultured neurons in response to BDNF. They found that the miRNA mir134 bound to sites in the $3^{\prime}$ UTR of one of the mRNAs, encoding LimKinase 1 (LimK1), and that modulation of mir134 concentrations altered LimK1 concentrations, which in turn altered spine structure. These findings are also consistent with miRNAs functioning to regulate translation at the synapse and indicate that such regulated translation is required for normal spine development. In the past year, studies in non-neuronal cells have revealed that components of the RNA interference pathway and targets of miRNAs localize to "RNA processing bodies," or "P-bodies" (Liu et al., 2005). Studies of the relationship between P-bodies and RNA granules in neurons may elucidate many aspects of translational regulation.

As outlined in the accompanying Mini-Review by Schuman et al. (2006), synaptic stimulation may serve to globally upregulate translation or to recruit translation of specific mRNAs. Given that such a large number of mRNAs appear to be present in dendrites, one might presume that distinct stimuli activate the translation of distinct mRNAs. In one example, however, stimuli that produce synaptic weakening (application of the mGluR agonist 3,4-dihydroxyphenylglycol) and stimuli that produce synaptic strengthening $(2 \times 100 \mathrm{~Hz}$ tetanic stimuli) of hippocampal synapse were both found to increase translation of elongation factor $1 \alpha(\mathrm{EF} 1 \alpha)$ in hippocampal dendrites (Huang et al., 2005; Tsokas et al., 2005). In one fascinating study, Schuman and col- 
leagues (Sutton et al., 2004) found that local translation in dendrites was negatively regulated by spontaneous release. These results suggest that one function of spontaneous release may be to sustain translational repression of localized mRNAs.

\section{What is the function of dendritic mRNA localization and regulated translation?}

Studies of fragile X mental retardation (FXMR), reviewed in the accompanying article by Greenough and colleagues (Grossman et al., 2006), highlight the importance of local translation for neuronal structure and function. The fragile X mental retardation protein (FMRP), mutated in patients with FXMR, is an mRNA-binding protein thought to function as a translational repressor. Loss of FMRP leads to abnormal spine structure, a hallmark of FXMR.

Elucidating the function of specific, locally translated mRNAs is technically challenging and requires new methodologies to differentiate between newly translated and preexisting protein and to resolve events occurring at individual synapses or subsets of synapses. Mayford and colleagues (Miller et al., 2002) undertook a creative approach to investigate the function of dendritically translated CaMKII $\alpha$ in which they expressed a CaMKII $\alpha$ transgene lacking the $3^{\prime}$ UTR (which contains the cis-acting dendritic targeting sequences) in CaMKII $\alpha$ null mice. Using this strategy, they succeeded in generating a mouse that expressed CaMKII $\alpha$ but lacked dendritically localized CaMKII $\alpha$ mRNA, allowing them to specifically assay the function of dendritically translated enzyme. These mutant mice showed deficits in the late phase of long-term plasticity at hippocampal synapses and in long-term memory. Furthermore, the postsynaptic density (PSD) in the mutant mice showed a selective loss of CaMKII $\alpha$ (and enrichment of CaMKII $\alpha$ ), which occurred although CaMKII $\alpha$ protein was present throughout the neuron, including in the dendrite. This finding suggests that locally synthesized CaMKII $\alpha$ is especially well incorporated into PSDs and indicates that the function of locally translated proteins may differ in subtle ways from that of somatically synthesized proteins.

Recent studies have shown that AMPA receptors are synthesized in dendrites in response to stimulation. Ju et al. (2004) found that chronic activity blockade increased the synthesis of a GluR1 reporter mRNA in dendrites and that acute activation of metabotropic glutamate receptors (mGluRs) or acute depolarization with $\mathrm{KCl}$ increased the synthesis of both GluR1 and GluR2. Using quantitative fluorescence in situ hybridization, Grooms et al. (2006) recently demonstrated that a substantial fraction of synaptic sites in hippocampal neurons contain GluR2 mRNA fluorescence clusters, consistent with strategic positioning and availability for "on-site" protein synthesis. Brief NMDAR activation, a signaling paradigm that drives endocytosis of AMPA receptors (AMPARs) (but not NMDARs) in hippocampal neurons in culture and induces long-term depression (chemical LTD) in hippocampal slices selectively depleted AMPAR mRNAs in dendrites. In contrast, group I mGluR activation elevated dendritic levels of AMPAR mRNAs by transport of mRNA from soma to dendrites. Bidirectional regulation of dendritic AMPAR mRNAs is a novel mechanism for long-lasting modifications of glutamate receptor composition and number and provides a potentially powerful means to effect long-lasting changes in synaptic efficacy.

In addition to a role for dendritic translation during plasticity, local translation in axonal growth cones has been shown to play a role in axon guidance and synapse formation (Campbell and Holt, 2001; Ming et al., 2002; Lyles et al., 2006) and local transla- tion in injured axons to contribute to regeneration (Zheng et al., 2001). Together, these findings indicate that mRNA localization and regulated translation provides a general mechanism whereby neurons can locally alter protein composition within discrete subcellular compartments. Understanding the mechanisms whereby mRNAs are localized and whereby their translation is locally regulated thus promises to provide important insights into many aspects of neuronal function and dysfunction.

\section{References}

Ashraf SI, McLoon AL, Sclarsic SM, Kunes S (2006) Synaptic protein synthesis associated with memory is regulated by the RISC pathway in Drosophila. Cell 124:191-205.

Campbell DS, Holt CE (2001) Chemotropic responses of retinal growth cones mediated by rapid local protein synthesis and degradation. Neuron 32:1013-1026.

Crino PB, Eberwine J (1996) Molecular characterization of the dendritic growth cone: regulated mRNA transport and local protein synthesis. Neuron 17:1173-1187.

Davis L, Banker GA, Steward O (1987) Selective dendritic transport of RNA in hippocampal neurons in culture. Nature 330:477-479.

Garner CC, Tucker RP, Matus A (1988) Selective localization of messenger RNA for cytoskeletal protein MAP2 in dendrites. Nature 336:674-677.

Grooms SY, Noh K-M, Regis R, Bassell GJ, Bryan M, Carroll RC, Zukin RS (2006) Activity bidirectionally regulates AMPA receptor mRNA abundance in dendrites of hippocampal neurons. J Neurosci, in press.

Grossman AW, Aldridge GM, Weiler IJ, Greenough WT (2006) Local protein synthesis and spine morphogenesis. J Neurosci 26:7151-7155.

Hachet O, Ephrussi A (2004) Splicing of oskar RNA in the nucleus is coupled to its cytoplasmic localization. Nature 428:959-963.

Hirokawa N (2006) mRNA transport in dendrites: RNA granules, motors, and tracks. J Neurosci 26:7139-7142.

Huang F, Chotiner JK, Steward O (2005) The mRNA for elongation factor $1 \alpha$ is localized in dendrites and translated in response to treatments that induce long-term depression. J Neurosci 25:7199-7209.

Huang YS, Carson JH, Barbarese E, Richter JD (2003) Facilitation of dendritic mRNA transport by CPEB. Genes Dev 17:638-653.

Ju W, Moroshita W, Tsui J, Gaietta G, Deerinck TJ, Adams SR, Garner CC, Tsien RY, Ellisman MH, Marlenka RC (2004) Activity-dependent regulation of dendritic synthesis and trafficking AMPA receptors. Nat Neurosci 7:244-253.

Kanai Y, Dohmae N, Hirokawa N (2004) Kinesin transports RNA: isolation and characterization of an RNA-transporting granule. Neuron 43:513-525.

Kiebler MA, DesGroseillers L (2000) Molecular insights into mRNA transport and local translation in the mammalian nervous system. Neuron 25:19-28.

Klann E, Dever TE (2004) Biochemical mechanisms for translational regulation in synaptic plasticity. Nat Rev Neurosci 5:931-942.

Kleiman R, Banker G, Steward O (1990) Differential subcellular localization of particular mRNAs in hippocampal neurons in culture. Neuron 5:821-830.

Knowles RB, Sabry JH, Martone ME, Deerinck TJ, Ellisman MH, Bassell GJ, Kosik KS (1996) Translocation of RNA granules in living neurons. J Neurosci 16:7812-7820.

Kohrmann M, Luo M, Kaether C, DesGroseillers L, Dotti CG, Kiebler MA (1999) Microtubule-dependent recruitment of Staufen-green fluorescent protein into large RNA-containing granules and subsequent dendritic transport in living hippocampal neurons. Mol Biol Cell 10:2945-2953.

Link W, Konietzko U, Kauselmann G, Krug M, Schwanke B, Frey U, Kuhl D (1995) Somatodendritic expression of an immediate early gene is regulated by synaptic activity. Proc Natl Acad Sci USA 92:5734-5738.

Liu J, Valencia-Sanchez MA, Hannon GJ, Parker R (2005) MicroRNAdependent localization of targeted mRNAs to mammalian P-bodies. Nat Cell Biol 7:719-723.

Lyford GL, Yamagata K, Kaufmann WE, Barnes CA, Sanders LK, Copeland NG, Gilbert DJ, Jenkins NA, Lanahan AA, Worley PF (1995) Arc, a growth factor and activity-regulated gene, encodes a novel cytoskeletonassociated protein that is enriched in neuronal dendrites. Neuron 14:433-445. 
Lyles V, Zhao Y, Martin KC (2006) Synapse formation and mRNA localization in cultured Aplysia neurons. Neuron 49:349-356.

Miller S, Yasuda M, Coats JK, Jones Y, Martone ME, Mayford M (2002) Disruption of dendritic translation of CaMKIIalpha impairs stabilization of synaptic plasticity and memory consolidation. Neuron 36:507-519.

Ming GL, Wong ST, Henley J, Yuan XB, Song HJ, Spitzer NC, Poo MM (2002) Adaptation in the chemotactic guidance of nerve growth cones. Nature 417:411-418.

Miyashiro K, Dichter M, Eberwine J (1994) On the nature and differential distribution of mRNAs in hippocampal neurites: implications for neuronal functioning. Proc Natl Acad Sci USA 91:10800-10804.

Moccia R, Chen D, Lyles V, Kapuya E, E Y, Kalachikov S, Spahn CM, Frank J, Kandel ER, Barad M, Martin KC (2003) An unbiased cDNA library prepared from isolated Aplysia sensory neuron processes is enriched for cytoskeletal and translational mRNAs. J Neurosci 23:9409-9417.

Pfeiffer EM, Huber KM (2006) Current advances in local protein synthesis and synaptic plasticity. J Neurosci 26:7147-7150.

Pinkstaff JK, Chappell SA, Mauro VP, Edelman GM, Krushel LA (2001) Internal initiation of translation of five dendritically localized neuronal mRNAs. Proc Natl Acad Sci USA 98:2770-2775.

Rook MS, Lu M, Kosik KS (2000) CaMKII $\alpha 3^{\prime}$ untranslated region-directed mRNA translocation in living neurons: visualization by GFP linkage. J Neurosci 20:6385-6393.

Schratt GM, Nigh EA, Chen WG, Hu L, Greenberg ME (2004) BDNF regulates the translation of a select group of mRNAs by a mammalian target of rapamycin-phosphatidylinositol 3-kinase-dependent pathway during neuronal development. J Neurosci 24:7366-7377.

Schratt GM, Tuebing F, Nigh EA, Kane CG, Sabatini ME, Kiebler M, Greenberg ME (2006) A brain-specific microRNA regulates dendritic spine development. Nature 439:283-289.

Schuman EM, Dynes J, Steward O (2006) Synaptic regulation of translation of dendritic mRNAs. J Neurosci 26:7143-7146.

Shin CY, Kundel M, Wells DG (2004) Rapid, activity-induced increase in tissue plasminogen activator is mediated by metabotropic glutamate receptor-dependent mRNA translation. J Neurosci 24:9425-9433.

Smith WB, Starck SR, Roberts RW, Schuman EM (2005) Dopaminergic stimulation of local protein synthesis enhances surface expression of GluR1 and synaptic transmission in hippocampal neurons. Neuron 45:765-779.

Steward O, Levy WB (1982) Preferential localization of polyribosomes under the base of dendritic spines in granule cells of the dentate gyrus. J Neurosci 2:284-291.
Steward O, Schuman EM (2003) Compartmentalized synthesis and degradation of proteins in neurons. Neuron 40:347-359.

Steward O, Worley PF (2001) Selective targeting of newly synthesized Arc mRNA to active synapses requires NMDA receptor activation. Neuron 30:227-240.

Steward O, Wallace CS, Lyford GL, Worley PF (1998) Synaptic activation causes the mRNA for the IEG Arc to localize selectively near activated postsynaptic sites on dendrites. Neuron 21:741-751.

Sung YJ, Weiler IJ, Greenough WT, Denman RB (2004) Selectively enriched mRNAs in rat synaptoneurosomes. Brain Res Mol Brain Res 126:81-87.

Sutton MA, Wall NR, Aakalu GN, Schuman EM (2004) Regulation of dendritic protein synthesis by miniature synaptic events. Science 304:1979-1983.

Tian QB, Nakayama K, Okano A, Suzuki T (1999) Identification of mRNAs localizing in the postsynaptic region. Brain Res Mol Brain Res 72:147-157.

Tiruchinapalli DM, Oleynikov Y, Kelic S, Shenoy SM, Hartley A, Stanton PK, Singer RH, Bassell GJ (2003) Activity-dependent trafficking and dynamic localization of zipcode binding protein 1 and $\beta$-actin mRNA in dendrites and spines of hippocampal neurons. J Neurosci 23:3251-3261.

Tongiorgi E, Righi M, Cattaneo A (1997) Activity-dependent dendritic targeting of BDNF and TrkB mRNAs in hippocampal neurons. J Neurosci 17:9492-9505.

Tongiorgi E, Armellin M, Giulianini PG, Bregola G, Zucchini S, Paradiso B, Steward O, Cattaneo A, Simonato M (2004) Brain-derived neurotrophic factor mRNA and protein are targeted to discrete dendritic laminas by events that trigger epileptogenesis. J Neurosci 24:6842-6852.

Tsokas P, Grace EA, Chan P, Ma T, Sealfon SC, Iyengar R, Landau EM, Blitzer $\mathrm{RD}$ (2005) Local protein synthesis mediates a rapid increase in dendritic elongation factor $1 \mathrm{~A}$ after induction of late long-term potentiation. J Neurosci 25:5833-5843.

Wells DG (2006) RNA-binding proteins: a lesson in repression. J Neurosci 26:7135-7138.

Zhang HL, Eom T, Oleynikov Y, Shenoy SM, Liebelt DA, Dictenberg JB, Singer RH, Bassell GJ (2001) Neurotrophin-induced transport of a betaactin mRNP complex increases beta-actin levels and stimulates growth cone motility. Neuron 31:261-275.

Zheng JQ, Kelly TK, Chang B, Ryazantsev S, Rajasekaran AK, Martin KC, Twiss JL (2001) A functional role for intra-axonal protein synthesis during axonal regeneration from adult sensory neurons. J Neurosci 21:92919303. 